\title{
HEGESZTHETŐSÉGI SZEMPONTOK NÖVELT SZILÁRDSÁGÚ ACÉLOKRA
}

\section{WELDABILITY STANDPOINTS FOR INCREASED STRENGHT STEELS}

\author{
Bagyinszki Gyula $^{1}$, Bitay Enikö ${ }^{2}$ \\ ${ }^{I}$ Óbudai Egyetem, Bánki Donát Gépész és Biztonságtechnikai Mérnöki Kar, \\ Magyarország, 1081 Budapest, Népszínház u.8, bagyinszki.gyula@bgk.uni-obuda.hu \\ ${ }^{2}$ Sapientia - Erdélyi Magyar Tudományegyetem, Marosvásárhelyi Kar, Románia, \\ 540485 Marosvásárhely (Koronka), Segesvári út 1.C., ebitay@ms.sapientia.ro
}

\begin{abstract}
During the welding process a metal base material is exposed to a rapid thermal cycle, this effect forms the joint crystallisation and also greatly affects the microstructure of the heat affected zone as well. The microstructural changing affects the properties and the stress range. This article reviews three important process groups - arc welding, resistance welding and high energy density welding - some weldability aspects.
\end{abstract}

Keywords: weldability, carbon equivalent, arc welding, resistance welding, high energy density welding

\section{Összefoglalás}

Hegesztéskor egy fémes anyag gyors hőciklusnak van kitéve, ami nemcsak a képződő varrat mikroszerkezetére hat, hanem jelentősen befolyásolja a höhatásövezet szövetszerkezetét is. A szerkezetváltozás pedig módosítja a tulajdonságokat és a feszültségi állapotot. Jelen cikk három fontos eljáráscsoport - az ívhegesztések, az ellenálláshegesztések és a nagy energiasűrüségü hegesztések néhány hegeszthetőségi aspektusával foglalkozik.

Kulcsszavak: hegeszthetöség, karbonegyenérték, ivhegesztés, ellenálláshegesztés, nagy energiasürüségü hegesztés

\section{Hegeszthetőség fogalomköre}

Egy fémes anyag akkor tekinthetö egy adott eljárással és célra kielégítő mértékben hegeszthetőnek, ha megfelelő munkarenddel (technológiai paraméterekkel) hegesztve olyan folytonos, fémes kötés hozható létre, amely megfelel az alkatrész helyi tulajdonságaiból és a szerkezet egészére gyakorolt hatásából származó követelményeknek. Alapvető szempont, hogy a hegesztett szerkezet a rá ható igénybevételeket megbízhatóan elviselje, de lényeges szempont az is, hogy vágással, képlékenyalakítással és hegesztéssel gazdaságosan elő lehessen állítani.

A hegesztett kötésekkel szemben általános elvárás, hogy a varrat a lehető legjobb tulajdonságú legyen, ami a leginkább akkor érhető el, ha a varratra és a hőhatás- övezetekre jellemző helyi tulajdonságok megegyeznek az alapanyagéval. Különösen igaz ez a megállapítás a szilárdsági méretezés alapjául szolgáló folyáshatárra és a 
(hideg)szívósságot befolyásoló átmeneti hömérsékletre.

\section{2. Ívhegesztési szempontok}

Ömlesztő ívhegesztéseknél - kritikus esetben - edződési ill. hidrogén okozta repedés is előfordulhat, aminek kockázata előmelegítés alkalmazásával csökkenthető. A megfelelő szívóssági és szilárdsági tulajdonságok megörzése korlátok közé szorított fajlagos hőbevitellel, azaz a „szakaszenergia” értékének pontos és gondos szabályozásával érhető el.

A elömelegítés mértékének meghatározá-sára több számítási eljárás is szolgál, ezek egyike az Uwer-Höhne módszer, amelyet szabvány is ajánl a finomszemcsés, gyengén ötvözött acélokhoz. Ez az alábbi karbonegyenértéket veszi alapul:

$C E T=C+\frac{M n+M o}{10}+\frac{C r+C u}{20}+\frac{N i}{40}$

A repedésveszély elkerüléséhez szükséges előmelegítési hőmérséklet meghatározásához a „súlyozott” vegyi összetételen (CET $\%$ kívül figyelembe kell venni a munkadarab mértékadó vastagságát (s mm), a diffúzióképes hidrogéntartalmat (Hd $\mathrm{ml} / 100 \mathrm{~g}$ fém), a fajlagos höbevitelt vagy szakaszenergiát $(q / v \mathrm{~kJ} / \mathrm{mm})$ is:

$T_{\text {elo }}=695 \cdot C E T+160 \cdot \operatorname{th}\left(\frac{s}{35}\right)+62$.
$H_{d}^{0,35}+(53 \cdot C E T-32) \cdot \frac{q}{v}-328$

Ez minimális értéket jelent, ezért indokolt esetben nagyobb hőmérsékletet is elö lehet írni. A hegesztési hőfolyamat hülési szakaszának jellemzésére a $t_{8,5 / 5}$ hűlési időt alkalmazzák, ami az $\mathrm{A}_{3}$ hőmérsékletről $500^{\circ} \mathrm{C}$-ra történő hülési időt jelenti. Az ezzel jellemzett hülési sebesség mértékét befolyásolja a kötés kialakítása, a hővezetési folyamatban résztvevő elemek száma és mérete. Ez alapján beszélhetünk kétdimenziós hővezetésről vékony lemezek esetén, illetve háromdimenziós hővezetésről vastag lemezek esetén. Rosenthal a lemezanyagokra vonatkozó 2D-s hővezetési modelljével olyan egyenletet vezetett le, amely a hömérséklet lefutását a hely és idő függvényében írja le. A $850{ }^{\circ} \mathrm{C}$-ról $500{ }^{\circ} \mathrm{C}$ ra való hủlés ideje a lemez felületén, a varrat középvonalában a következő:

$$
\begin{aligned}
& t_{8,5 / 5}=\frac{P^{2}}{4 \cdot \pi \cdot \lambda \cdot c \cdot \rho \cdot v_{h}^{2} \cdot s^{2}} \cdot\left[\frac{1}{\left(500-T_{0}\right)^{2}}-\right. \\
& \left.\frac{1}{\left(850-T_{0}\right)^{2}}\right]
\end{aligned}
$$

ahol: $P$ az effektív hőteljesítmény [W], $\lambda$ a hövezetési tényező $[\mathrm{W} / \mathrm{mm} \cdot \mathrm{K}], c$ a fajhő $[\mathrm{J} / \mathrm{g} \cdot \mathrm{K}], \rho$ a sürüség $\left[\mathrm{g} / \mathrm{mm}^{3}\right], v_{h}$ a hegesztési sebesség $[\mathrm{mm} / \mathrm{s}], s$ a lemezvastagság $[\mathrm{mm}], T_{0}$ az előmelegítési hőmérséklet $\left[{ }^{\circ} \mathrm{C}\right]$.

Ha hegesztéskor a megengedhető hülési időtartomány felső határához közelítünk, kedvezőbb ütőmunka értékek érhetők el. Ha az alsó határhoz tartunk, keménységnövekedéssel kell számolni, s ezzel együtt fennáll a repedésképződés veszélye is.

Nemesített nagyszilárdságú acélok esetében az előmelegítési hőmérséklet meghatáro-zása az Uwer-Höhne módszer alapján lehetséges. Az elöirt minimális értéknél célszerü - a hűlési idők figyelembevéte-lével _ - magasabb hőmérsékletet alkalmazni a repedések elkerülése céljából.

\section{Ellenálláshegesztés szempontjai}

$\mathrm{Az}$ ömlesztve sajtoló ellenállásponthegesztésnél elvárás, hogy az elöírt méretű pontkötéseket reprodukálhatóan, repedésmentesen, az alapanyagra és a kötéstípusra jellemző terhelhetőséggel lehessen létrehozni. A hegeszthetöség megítélése az eljárás jellegzetességei (rendkívül gyors hevítés, kisméretü hegfürdő, nyomófeszültség és az elektródák okozta intenzív höelvonás alatti kristályosodás) miatt eltér az ívhegesztésekétől.

A ponthegeszthetőség vizsgálati kritériumaként a kötések maximális keménységét és a pontkötések valamilyen 
vizsgáló eljárásához kötött kedvezötlen törési módjának megjelenését szokás megadni. Az alapanyag kémiai összetételének a hatása a ponthegeszthetöség vizsgálata során is a karbonegyenértékkel fejezhető ki:

$C E_{R S W}=C+\frac{S i}{30}+\frac{M n}{20}+2 \cdot P+4 \cdot S \leq$ $0,24 \%$

Ezt a karbonegyenértéket növelt szilárdságú acéllemezek hegeszthetöségének minősíté-sére vezették be. A 0,24 \%-os határérték a kedvezötlen törési mód megjelenési határát jelöli, ahol a kötések keresztszakító és nyíró-szakító erejének hányadosa csökkenni kezd. A határérték felett - a szokásos ponthegesztési technológia alkalmazása esetén - a hőhatásövezetben, illetve a heglencsében is keletkezhet repedés vagy üzem közbeni ridegtörés következhet be.

A duálfázisú acélok ferrites szövetszerkezete jelentős mennyiségü, kis karbontartalmú, ún. lágy martenzitet tartalmaz, és az acél ötvözői ill. mikroötvözői az ausztenitesedett anyagtérfogatok (varrat és a hőhatásövezet egy része) edződését egyaránt elősegítik. A kedvezőtlen szövetszerkezetet a hülési sebesség lassításával kerülhetjük el. Ellenállásponthegesztéskor ez praktikusan a szakaszos energiabevitel alkalmazását, vagy a hegesztési föidő után beiktatott ún. „in machine" (gépben végzett) hőkezelö ciklus alkalmazását jelenti.

A duálfázisú acélok ponthegesztéséhez a - lágyacélokhoz viszonyítottan - nagyobb fajlagos elektromos ellenállásukból, nagyobb melegszilárdságukból és a rövid idejü höhatás alatti megeresztésállóságukból következöen mintegy $20 \ldots .25 \%$-kal nagyobb elektróderő szükséges. A nagyobb elektróderő okozta ellenálláscsökkenést kompenzáló, $\quad 10 \ldots 20 \%$-kal nagyobb áramerősség és ugyanolyan mértékkel hosszabb hegesztési föidő javasolt. További kötésszilárdság növekedés várható nagyobb elektródátmérő és más elektródacsúcsgeometria alkalmazásától.

\section{Nagy energiasűrüségú hegesztés}

Ha a lézeres és az elektronsugaras hegesztés viszonylag vékony lemezeken történik, akkor feltételezhető az is, hogy függőleges irányban nem lépnek fel jelentős változások és a sugár egy mozgó vonalforrással helyettesíthető. A közölt teljesítmény és a hegesztési sebesség (fajlagos hőbevitel) változtatásával a varrat szélessége befolyásolható, azaz adott esetben növelhetö is.

$\mathrm{Az}$ amúgy is csekély deformáció csökkentésének ill. szabályozásának technológiai módszerei a bevitt hömennyiségen és a varratalakon keresztül érvényesülnek. A legkeskenyebb varrat és a csaknem párhuzamos varratoldal a lehetö legkisebb sugárteljesítménnyel (de az elérhető legnagyobb teljesítménysürüséggel) és a megengedhető legnagyobb hegesz-tési sebességgel készíthetö.

A nagy teljesítménysürüség hatására gyorsan létrejövő és mély ömledéket fajlagosan nagy határfelület választja el a szilárd anyagtól, ill. a megömlesztett térfogat kicsi a munkadarab össztérfogatához képest, így az ömledék igen gyorsan hül. A hevítés és a lehülés sebességének ilyen megnövekedése jelentősen megváltoztatja, eltolja az acélok kritikus átalakulási hőmérsékleteit és ez befolyásolja a fázisátalakulást szenvedő anyag mennyiségét. A hőhatásövezet gyors hevítése kiválthatja igen nagy számú, elnyúlt alakú ausztenitcsíra keletkezését és a túlhevülés ellenére sem lép fel szemcsedurvulás (legfeljebb az eredeti szemcsenagyság öröklődik). A varrat finom szemcseszerkezete gátló tényezöje a repedések keletkezésének.

A legtöbb ötvözetlen és gyengén ötvözött acélban - a hegesztés utáni hülési 
sebességtől függően - többé-kevésbé martenzites, bainites szövetszerkezet alakul ki, mely kemény és repedésre hajlamosít. Ha lehet, törekedni kell a varrat hülési sebességének csökkentésére. Ez megtehetö a sugár defókuszolásával vagy lengetésével, de még inkább a darab előmelegítésével és/vagy hegesztés utáni esetleges hőntartásával. A maximális varratfémkeménységet elörejelző összefüggés ötvözetlen és gyengén ötvözött acélok esetére:

$H V_{10 \max }=\left(\frac{840}{t_{8 / 5}^{0,22}} \cdot C_{e}+58\right) \pm 66$

ahol:

$C_{e}=C \%+\frac{M n \%}{2,4}+\frac{S i \%}{24}+\frac{N i \%}{14}+\frac{C r \%}{16}+$

$\frac{M o \%}{60}$

$t_{8 / 5}=\frac{1}{4 \cdot \pi \cdot \lambda \cdot c \cdot \rho} \cdot\left[\frac{0,8 \cdot P}{v_{h} \cdot s}\right]^{2} \cdot\left[\frac{1}{\left(500-T_{0}\right)^{2}}-\right.$

$\left.\frac{1}{\left(800-T_{0}\right)^{2}}\right]$

Az acélok elektronsugaras és lézeres hegeszthetőségénél is fontos, hogy a két fő szennyező és a C-tartalom értéke maximalizálandó $(\mathrm{P} \%+\mathrm{S} \% \leq 0,11 \% ; \mathrm{C} \%$ $\leq 0,35 \%$ ) a meleg- ill. a hidegrepedés, valamint az azokat elősegítő káros szövetszerkezeti változások elkerülése érdekében. Természetesen a hegesztési munkarend elemeit is hozzá kell igazítani az anyagösszetételhez. Repedés- és porozitásmentes lézerrel hegesztett varratok létrehozása is az acélgyártás során visszamaradó szennyező- ill. zárványtartalom mennyiségétől függ, a fajlagos hőbevitel (teljesítmény, hegesztési sebesség) mellett.

Az eltérő minőségü fémek hegeszthetőségé-nek két alapvető feltétele van:

- a két fém képes legyen egyidejüleg megömleni és közös ömledéket képezni. Ez a feltétel nehezen teljesül, ha a két fém olvadáspontja messze esik egymástól, vagy a hővezetőképességük nagyon különbözik. Ezért ha szükséges, a sugarat aszimmetrikusan irányítják a nehezebben megömlő fém felé.

- a két fém metallurgiailag kompatibilis legyen, azaz ne keletkezzenek megengedhetetlen intermetallikus fázisok, átmeneti vegyületformák a hegesztési folyamat során. Ha két ötvözet kötéséről van szó, még hozzávetölegesen sem lehet következtetést levonni az egyensúlyi diagramokból, hanem elözetes kísérleteket kell végezni.

\section{Következtetések}

A nagyobb folyáshatárú fémes alapanyagok alkalmazása a hegesztett termékekben kisebb szelvényvastagságok alkalmazását teszi lehetővé, ami önsúlycsökkenéshez és kisebb tömegü varratokhoz vezet. Ez csökkenti a hozaganyag szükségletet, a hegesztéshez felhasznált munkaidőt és energiát. A vékonyabb szelvény, a kisebb hegesztési hőbevitel általában mérsékli a keletkező termikus feszültségeket (sőt az ezekkel összefüggő repedésveszélyt), javítja a termék használati tulajdonságait.

\section{Szakirodalmi hivatkozások}

[1] Komócsin Mihály: Nagyszilárdságú acélok és hegeszthetöségük, Miskolci Egyetem, 2008

[2] Gáspár Marcell Gyula - Balogh András: Nagyszilárdságú acélok hegesztéstechnológiájának fejlesztése a hülési idö elemzésével, Miskolci Egyetem Mechanikai Technológiai Tanszék

[3] Balogh A., Prém L.: Ferrit-martenzites (DP) acél vékonylemezek ellenállás-ponthegeszthetösége, Gép LXIV. évfolyam 8. szám, 1317. oldal

[4] Bagyinszki Gy., Bitay E.: Nagy energiasürüségü eljárások hegeszthetőségi szempontjai, XVII. Fiatal Müszakiak Tudományos Ülésszaka, Kolozsvár, 2012. március 22-23.; Müszaki Tudományos Füzetek - Erdélyi Múzeum-Egyesület kiadványa (ISSN 2067 - 6 808) 13-18. o. 